\title{
19 School belonging policy
}

\author{
Kelly-Ann Allen, DeLeon L. Gray, Gökmen \\ Arslan, Kathryn Riley, Dianne Vella-Brodrick, and \\ Lea Waters
}

\section{How to use this policy}

School belonging as a concept is unique to school environments and is influenced by a range of factors including school climate, cultural processes, broader societal issues, and historical/current events. A policy on school belonging enables school communities to develop collaborative engagement with staff, students, and families. School networks also have a significant role to play in helping create the conditions for belonging. This policy is structured to allow users to adapt it in a manner that serves the local, immediate demands of their contexts. Policies are most effective when they are known and implemented by the people who are their intended audience. For a policy on school belonging, it is recommended that effort is invested into ensuring that key stakeholders (e.g., students, parents, school staff, and community members) have a sense of agency and voice, and a role in shaping the policy content. The process of refining the school belonging policy in this way will be as important as the policy itself. School leaders should ensure that policies are embedded in day-to-day practices by using them in practical and tangible ways. A policy on school belonging could be incorporated into school rules, displayed as a poster in a classroom, or printed in the student diary. School belonging should be an explicit school value. Gray et al. (2018) recommend that schools develop teams to review existing policies and practices within a school to ensure that all methods within a school facilitate belonging for students and do not unintentionally ostracise or exclude specific individuals or groups.

[To adapt and use this policy, delete or modify the text as indicated]

\section{[INSERT name of school] Student belonging policy}

\section{Rationale}

School belonging - or a sense of psychological membership at schoolrepresents the extent to which students feel accepted, respected, included, and supported in their school environment (Goodenow, 1993). When students have a sense of school belonging, they feel confident that they fit in and feel 
safe at school (Riley, 2017). A sense of school belonging is a complex and multifaceted phenomenon that is influenced by many factors and variables within a school setting, including individual differences (Allen et al., 2018a). Yet it is important to keep in mind that policies can promote or hinder the extent to which all students - regardless of their background, ability status, gender identity, racial identity, or sexual orientation-have opportunities to belong at school.

School belonging has been found to be an essential component for student wellbeing, academic outcomes, and physical health (Allen et al., 2018a; Arslan, 2018; Arslan et al., 2020; Abdollahi, 2020) and should be valued and prioritised in schools (Allen et al., 2018b). It is estimated that approximately 1 in 3 students does not feel a sense of belonging to school (OECD, 2019). Therefore, to address this issue a student's sense of school belonging should be valued and nurtured within school settings (Allen, 2020a).

\section{Purpose}

The purpose of this policy is to outline the shared responsibility of belonging for the whole school community inclusive of parents, staff, teachers, students, and school leadership. Every individual within a school community can help create a climate of belonging.

\section{Scope}

This policy includes the role that students, teachers, staff, school leaders, and parents play in promoting a sense of belonging for others in the [INSERT name of school] community.

[INSERT specific roles and responsibilities of individuals or teams within the school who may be managing a whole school approach to school belonging].

\section{Policy statement}

\section{School management}

[INSERT name of school] is committed to providing consistent and structured opportunities for students to build positive relationships with each other, their teachers, their parents, and staff at our school. Teachers at our school know their students and seek feedback from their students about their relationship, rapport, and level of engagement. Through school-wide events, assessments, and programming, we provide both time and space for teachers to build relationships with their students (Shochet et al., 2011; Waters et al., 2010).

School leadership (e.g., principals/administrators) create formal structures to consult students on school policy decisions and build their sense of agency. Their voices are represented in policy-making decisions (in the form of a diverse student advisory committee comprised of students from various 
socioeconomic backgrounds, linguistic backgrounds, ethnic backgrounds, performance levels, and (dis)ability statuses).

Efforts are made at [INSERT name of school] to ensure continuity of care for students during their time at school (Garcia-Reid et al., 2005; Whitlock, 2006).

Our school endeavours to employ teachers who are not only skilled in content areas but also culturally competent and sensitive to students' social and emotional needs (Battistich et al., 1996; Whitlock, 2006).

[INSERT name of school] ensures that teachers have access to professional development that encompasses improving student-teacher relationships and ways to foster positive, safe, and fair classroom environments that build on the strengths and assets that students bring into the classroom (Allen et al., 2011; Ingersoll \& Strong, 2011).

[INSERT name of school] has strategies in place to evaluate, build, or strengthen a teacher's sense of belonging to school (e.g., teacher mentoring programs, induction programs for new staff) (Ingersoll \& Strong, 2011).

[INSERT name of school] implements programs, interventions, and/or classroom-based curriculum that teaches social, emotional, and cultural competencies to students (Allen et al., 2017; Frydenberg, 2009; SchonertReichl \& Lawlor, 2010).

[INSERT name of school] has a comprehensive and tiered approach to preventing, identifying, and managing mental health concerns (Waters et al., 2010; Wilkinson-Lee et al., 2011; Roche \& Kuperminc, 2012).

\section{Teachers}

Staff at [INSERT name of school] acknowledge that a positive student-teacher relationship is one of the most effective ways to build a student's sense of school belonging (Allen et al., 2018a).

Teachers at [INSERT name of school] are encouraged to provide personal support, affirmation, and inspiration for learning, as well as academic support to students (Shochet et al., 2011; Waters et al., 2010).

Teachers at [INSERT name of school] demonstrate fair and consistent restorative justice approaches to issues of school discipline (Sakiz, 2012).

Teachers at [INSERT name of school] provide students with opportunities for personal agency over their learning (Wentzel, 1998; Ryzin et al., 2009).

Teachers make regular (positive) contact with parents for proactive and positive communication (Allen et al., 2020; Reschly et al., 2008).

Teachers actively emphasise the value of what students are learning for uplifting their communities, honouring their ancestral heritage, and combatting issues of social justice and social inequality in school and society. 
Teachers are supported by administrators in recognising and responding to the way larger societal, systemic, and structural inequalities are impacting historically marginalised students in their schools.

Teachers actively build upon the knowledge systems, experiences, and perspectives that students bring as assets into the classroom and school.

Teachers ensure that students understand the importance and purpose of what students are learning (Walker, 2012; Battistich et al., 1996; Whitlock, 2006).

\section{Students}

[INSERT name of school] encourages students to support each other academically as well as personally (e.g., peer mentor programs, study clubs, homework group) (Reschly et al., 2008; Ryzin et al., 2009).

[INSERT name of school] has an induction procedure for new students and transition programs at key transition points for students (Ryzin et al., 2009).

All students at [INSERT name of school] are expected to be inclusive, respectful, and affirming toward each other (Goodenow \& Grady, 1993; Reschly et al., 2008).

Students are encouraged to have high personal expectations and goals around their learning and social wellbeing, with assurance that teachers will support them in reaching these high standards (Heaven et al., 2002; Klem \& Connell, 2004; Guthrie \& Davis, 2003; Zimmer-Gembeck et al., 2006).

At [INSERT name of school] all students are encouraged to use their personal strengths (Proctor et al., 2011) and are made aware that they all have a role to play in contributing to a culture of belonging at their school (Allen, 2020b).

\section{Parents}

Parents of [INSERT name of school] are encouraged to be involved in school life in meaningful ways (Reschly et al., 2008).

[INSERT name of school] provides multiple communication channels for parents that consider their needs and preferences (Reschly et al., 2008).

The school seeks feedback from parents about their overall satisfaction with the [INSERT name of school] and communication from teachers and school leaders more generally (Reschly et al., 2008).

[INSERT name of school] aims to make parents feel welcomed when they are at school.

Educational opportunities for parents that enhance their connectedness and belonging with the school and their children are available throughout the year (Kelly et al., 2012; Stoddard et al., 2011; Waters et al., 2010). 


\section{Rating of evidence base}

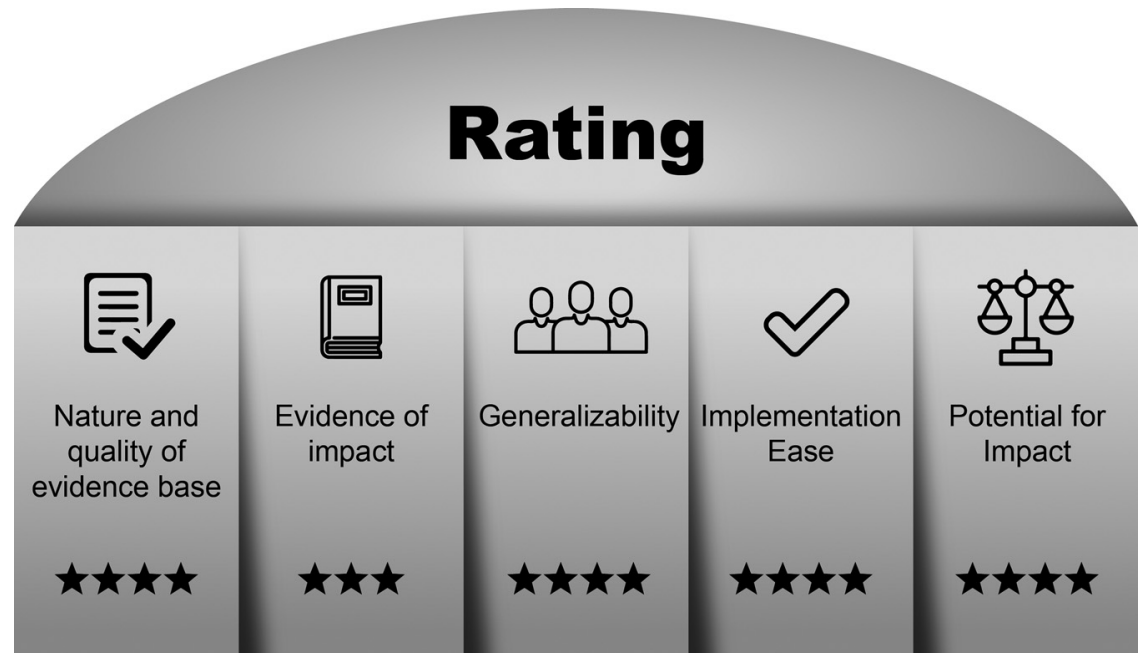

Figure 19.1. School Belonging Rating of Evidence.

\section{Authorship}

Dr Kelly-Ann Allen, Monash University

Dr DeLeon L. Gray, North Carolina State University

Dr Gökmen Arslan, Mehmet Akif Ersoy University

Professor Kathryn Riley, University College London

Professor Dianne Vella-Brodrick, University of Melbourne and

Professor Lea Waters, University of Melbourne

[INSERT RELEVANT STAFF MEMBERS]

\section{Related policy and documents}

[INSERT RELEVANT POLICY AND DOCUMENTS]

Inclusion policy

Wellbeing policy

Safety policy

Counselling policy

Anti-bullying and discrimination policy

Staff belonging policy

\section{Date of ratification}

This policy was ratified on the [INSERT DATE]. 


\section{Date of review}

This policy will be reviewed by [INSERT DATE].

\section{Recommended reading}

Allen, K. A. (2020). Psychology of belonging. Routledge.

Allen, K. A., \& Kern, P. (2019). Boosting school belonging in adolescents: Interventions for teachers and mental health professionals. Routledge.

Allen, K. A., \& Boyle, C. (Eds.) (2018). Pathways to belonging: Contemporary research in school belonging. BRILL | Sense.

Allen, K. A., \& Kern, M. L. (2017). School belonging in adolescents: Theory, research, and practice. Springer Social Sciences.

\section{References}

Abdollahi, A., Panahipour, S., Tafti, M. A., \& Allen, K. A. (2020). Academic hardiness as a mediator for the relationship between school belonging and academic stress. Psychology in the Schools, 57(5), 823-832.

Allen, J. P., Pianta, R. C., Gregory, A., Mikami, A. Y., \& Lun, J. (2011). An interaction-based approach to enhancing secondary school instruction and student achievement. Science, 333(6045), 1034-1037.

Allen, K. A. (2020a). Psychology of belonging. Routledge.

Allen, K.A. (2020b). School belonging: The many ways to belong. Frontiers for Young Minds.

Allen, K. A., Slaten, C., Arslan, G., Roffey, S., Craig, H., \& Vella-Brodrick, D. (2020). School belonging: The importance of student-teacher relationships. In P. Kern \& M. Streger (Eds.), The handbook of positive education. Palgrave \& Macmillan.

Allen, K. A., Kern, M. L., Vella-Brodrick, D., Waters, L., \& Hattie, J. (2018a). What Schools Need to Know about Belonging: A meta-analysis. Educational Psychology Review, 30(1), 1-34.

Allen, K., Kern, P., Vella-Brodrick, D., \& Waters, L. (2018b). Understanding the priorities of Australian secondary schools through an analysis of their mission and vision statements. Educational Administration Quarterly, 54(2), 249-274.

Allen, K. A., Vella-Brodrick, D., \& Waters, L. (2017). School belonging and the role of social and emotional competencies in fostering an adolescent's sense of connectedness to their school. In E. Frydenberg, A. J. Martin, \& R. J. Collie (Eds.), Social and Emotional Learning in Australia and the Asia-Pacific: Perspectives, Programs and Approaches (1st ed.) (pp. 83-99). Springer.

Arslan, G. (2018). Exploring the association between school belonging and emotional health among adolescents. International Journal of Educational Psychology, 7(1), 21-41.

Arslan, G., Allen, K., \& Ryan, T. (2020). Exploring the impacts of school belonging on youth wellbeing and mental health: A longitudinal study. Child Indicators Research, 13, 1619-1635. 
Battistich, V., Schaps, E., Watson, M., \& Solomon, D. (1996). Prevention effects of the child development project early findings from an ongoing multisite demonstration trial. Journal of Adolescent Research, 11(1), 12-35.

Frydenberg, E., Care, E., Freeman, E., \& Chan, E. (2009). Interrelationships between coping, school connectedness and wellbeing. Australian Journal of Education, 53(3), 261-276.

Garcia-Reid, P. G., Reid, R. J., \& Peterson, N. A. (2005). School engagement among Latino youth in an urban middle school context: Valuing the role of social support. Education and Urban Society, 37(3), 257-275.

Goodenow, C. (1993). The psychological sense of school membership among adolescents - scale development and educational correlates. Psychology in the Schools, 30(1), 79-90.

Goodenow, C., \& Grady, K. E. (1993). The relationship of school belonging and friends' values to academic motivation among urban adolescent students. Journal of Experimental Education, 62(1), 60-71.

Gray, D. L., Hope, E. C., \& Matthews, J. S. (2018). Black and belonging at school: A case for interpersonal, instructional, and institutional opportunity structures. Educational Psychologist, 53(2), 97-113.

Guthrie, J. T., \& Davis, M. H. (2003). Motivating struggling readers in middle school through an engagement model of classroom practice. Reading \&Writing Quarterly, 19(1), 59-85.

Heaven, P. C., Mak, A., Barry, J., \& Ciarrochi, J. (2002). Personality and family influences on adolescent attitudes to school and self-rated academic performance. Personality and Individual Differences, 32(3), 453-462.

Ingersoll, R., \& Strong, M. (2011). The impact of induction and mentoring programs for beginning teachers: A critical review of the research. Review of Education Research, 81(2), 201-233.

Kelly, A. B., O'Flaherty, M., Toumbourou, J.W., Homel, R., Patton, G. C., White, A., \& Williams, J. (2012). The influence of families on early adolescent school connectedness: evidence that this association varies with adolescent involvement in peer drinking networks. Journal of abnormal child psychology, 40(3), 437-447.

Klem, A. M., \& Connell, J. P. (2004). Relationships matter: Linking teacher support to student engagement and achievement. Journal of School Health, 74(7), 262-273.

Organisation for Economic and Cooperative Development [OECD]. (2019). PISA 2018 results (Volume III): What school life means for students' lives. OECD.

Proctor, C., Tsukayama, E., Wood, A. M., Maltby, J., Eades, J. F., \& Linley, P. A. (2011). Strengths gym: The impact of a character strengths-based intervention on the life satisfaction and well-being of adolescents. The Journal of Positive Psychology, 6(5), 377-388.

Reschly, A. L., Huebner, E. S., Appleton, J. J., \& Antaramian, S. (2008). Engagement as flourishing: The contribution of positive emotions and coping to adolescents' engagement at school and with learning. Psychology in the Schools, 45(5), 419-431.

Riley, K. (2017). Place, belonging and school leadership: Researching to make the difference. Bloomsbury.

Roche, C., \& Kuperminc, G. P. (2012). Acculturative stress and school belonging among Latino youth. Hispanic Journal of Behavioral Sciences, 34(1), 61-76.

Ryzin, M. J., Gravely, A. A., \& Roseth, C. J. (2009). Autonomy, belongingness, and engagement in school as contributors to adolescent psychological wellbeing. Journal of Youth and Adolescence, 38(1), 1-12. 
Sakiz, G. (2012). Perceived instructor affective support in relation to academic emotions and motivation in college. Educational Psychology: An International Journal of Experimental Educational Psychology, 32(1), 63-79.

Schonert-Reichl, K., \& Lawlor, M. (2010). The effects of a mindfulness-based education program on pre- and early adolescents' well-being and social and emotional competence. Mindfulness, 1(3), 137-151.

Shochet, I. M., Smith, C. L., Furlong, M. J., \& Homel, R. (2011). A prospective study investigating the impact of school belonging factors on negative affect in adolescents. Journal of Clinical Child \& Adolescent Psychology, 40(4), 586-595.

Stoddard, S. A., McMorris, B. J., \& Sieving, R. E. (2011). Do social connections and hope matter in predicting early adolescent violence? American Journal of Community Psychology, 48(3-4), 247-256.

Walker, C. O. (2012). Student perceptions of classroom achievement goals as predictors of belonging and content instrumentality. Social Psychology of Education, 15(1), 97-107.

Waters, S., Cross, D., \& Shaw, T. (2010). Does the nature of schools matter? An exploration of selected school ecology factors on adolescent perceptions of school connectedness. British Journal of Educational Psychology, 80(3), 381-402.

Wentzel, K. R. (1998). Social relationships and motivation in middle school: The role of parents, teachers, and peers. Journal of Educational Psychology, 90(2), 202-209.

Whitlock, J. (2006). The role of adults, public space, and power in adolescent community connectedness. Journal of Community Psychology, 35(4), 499-518.

Wilkinson-Lee, A. M., Zhang, Q., Nuno, V. L., \& Wilhelm, M. S. (2011). Adolescent emotional distress: The role of family obligations and school connectedness. Journal of Youth and Adolescence, 40, 221-230.

Zimmer-Gembeck, M., Chipuer, H., Hanisch, M., Creed, P., \& McGregor, L. (2006). Relationships at school and stage-environment fit as resources for adolescent engagement and achievement. Journal of Adolescence, 29, 911-933. 